\title{
Metastable nanodiamond linked to serpentinization of olivine
}

\author{
NÚRIA PUJOL-SOLÀ ${ }^{1}$, ANTONIO GARCIA-CASCO ${ }^{2,3}$, \\ JOAQUÍN A. PROENZA ${ }^{1}$, JOSE MARIA GONZÁLEZ- \\ JIMÉNEZ ${ }^{2}$, ADOLFO DEL CAMPO ${ }^{4}$, VANESSA COLÁS ${ }^{5}$, \\ ÀNGELS CANALS ${ }^{1}$, ANTONIO SÁNCHEZ-NAVAS ${ }^{2}$ AND \\ JOSEP ROQUÉ-ROSELL ${ }^{1}$ \\ ${ }^{1}$ Universitat de Barcelona \\ ${ }^{2}$ Universidad de Granada \\ ${ }^{3}$ Instituto Andaluz de Ciencias de la Tierra (CSIC-UGR) \\ ${ }^{4}$ Instituto de Cerámica y Vidrio - CSIC \\ ${ }^{5}$ Departamento de Procesos Litosféricos, Instituto de Geología, \\ Universidad Nacional Autónoma de Mexico \\ Presenting Author: nurpss@gmail.com
}

Low pressure oceanic gabbros and chromitites from the MoaBaracoa ophiolitic massif (eastern Cuba) contain olivine grains crosscut by trails of secondary $\mathrm{CH}_{4}$-bearing fluid inclusions. Some of these fluid inclusions host nanodiamond $(200-300 \mathrm{~nm})$ associated with magnetite and serpentine, and locally superreduced metallic $\mathrm{Si}$, suggesting that their formation took place during serpentinization of the host olivine at low pressure and temperature. Such solid-fluid assemblage is encapsulated well below the polished mineral surface, thus, ruling out anthropogenic contamination during sample preparation. We suggest a mass-balance model in which infiltration of ocean water into the oceanic lithosphere forms fluid inclusions in olivine which, once sealed, act as closed-system micro-reactors where precipitation of metastable diamond takes place upon serpentinization of olivine and associated coupled production of magnetite by oxidation of $\mathrm{Fe}^{2+}$ and strong reduction of infiltrated $\mathrm{H}_{2} \mathrm{O}-\mathrm{CO}_{2}$ fluid mixtures. Progressive reduction of $\mathrm{C}-\mathrm{H}-\mathrm{O}$-rich fluids eventually reaches $\mathrm{C}$ saturation, forming graphite or metastable diamond. Thermodynamic modelling suggest that metastable diamond in fluid inclusions can grow upon extreme reduction of the fluid $\left(\operatorname{logfO} \mathrm{O}_{2}(\mathrm{MPa})=-45.3 ; \Delta \operatorname{logfO}_{2}\right.$ [IronMagnetite] $=-6.5)$ at a reference $\mathrm{P}-\mathrm{T}$ point typical for serpentinization (i.e., $350{ }^{\circ} \mathrm{C}$ and $100 \mathrm{MPa}$ ). These findings imply that the formation of metastable diamond at low pressure in partially serpentinized olivine from mafic and ultramafic rocks can be a widespread process in modern and ancient oceanic lithosphere. However, the small size of diamond and its scarcity in fluid inclusions could explain its apparent absence in other case studies of altered oceanic rocks. The presence of diamond and other highly reduced phases in oceanic rocks, in particular chromitites, cannot hence be taken as a general indication of deep mantle recycling at ultra-high pressure conditions. 